\title{
HUBUNGAN KELEKATAN IBU DAN ANAK DENGAN PERILAKU BULLYING ANAK REMAJA DI SMA NEGERI 3 KOTA KUPANG
}

\author{
Elyona Bees \\ Fakultas Psikologi Universitas Kristen Satya Wacana Salatiga \\ elyona.bees@gmail.com \\ Berta Esti Ari Prasetya \\ Staf Pengajar Fakultas Psikologi Universitas Kristen Satya Wacana Salatiga \\ bertaprasetya@gmail.com
}

\begin{abstract}
Abstrak
Di Indonesia banyak kejadian yang menunjukkan bahwa dunia pendidikan Indonesia telah terjadi tindakan bullying terhadap siswanya. Salah satu faktor yang dapat membantu mengurangi fenomena bullying adalah kelekatan antara ibu dan anak. Penelitian ini bertujuan untuk mengetahui apakah ada hubungan yang negatif dan signifikan antara kelekatan ibu dan anak dengan perilaku anak remaja di SMA Negeri 3 di kota kupang. Metode penumpulan data yang digunakan dalam penelitian ini adalah skala psikologi. Skala yang digunakan dalam penelitian ini yaitu skala bullying yang di susun dalam Lizt $(2005)(\alpha=0,895)$ dan skala kedua yaitu, Inventory of Parent and Peer Attachment (IPPA) yang di adaptasi dari skala kelekatan antara ibu dan anak yang disusun oleh Armsden, dkk (2001) $(\alpha=0,859)$. Partisipan dalam penelitian ini adalah remaja kelas XII SMA Negeri 3 Kupang dan menggunakan teknik pengambilan sampling jenuh dengan total subjek sebanyak 198 orang. Pengujian hipotesis dan korelasi antara kelekatan ibu dan anak dengan perilaku bullying akan menggunakan uji korelasi Spearman Rho. Hasil penelitian ini menunjukan adanya hubungan negatif tetapi tidak signifikan antara perilaku Bullying dengan kelekatan antara ibu dan anak $(r=-0.115, p<0,05)$.

Kata kunci : Perilaku Bullying, Kelekatan Ibu dan Anak, remaja.
\end{abstract}

\begin{abstract}
In indonesia numerous occurrences indicating that indonesia education world has happened the act of bullying toward their students. One factor that can help reduce the phenomenon of bullying are attachment between mother and child. This study attempts to ascertain whether there are a negative and welfare between kelekatan mother and child with the behavior teenager in high school the 3 in kupang city. Method penumpulan the data used the research is a scale psychology. The scale used in this research the scale of bullying in flats in lizt ( 2005 ) ( $\alpha=0,895)$ and scale of both the , inventory of parent and peer attachment (ippa ) in adaptation of the scale kelekatan between mother and child compiled by armsden, etc ( 2001) $(\alpha=0,859)$. Participants in research is a teenager class XII public SMA 3 kupang and uses the technique the sampling saturated with a total of about 198 the subject. The testing of hypotheses and the correlation attacment between mother and child $(r=-0.115, p<0,05)$.

Keywords : Bullying behavior, attachment mother and child, teenager.
\end{abstract}




\section{PENDAHULUAN}

Masa remaja seringkali disebut sebagai masa transisi, karena pada masa remaja, anakanak mulai meninggalkan perilaku kanak-kanak dan mencari identitas yang baru. Terkait dengan masa peralihan tersebut, Erikson (dalam Hurlock, 1999) menyebutkan bahwa status individu pada masa itu tidaklah jelas dan terdapat keraguan akan peran yang harus dilakukannya. Tidak semua remaja dapat memenuhi tugas-tugas perkembangan dengan baik. Menurut Hurlock (1999) ada beberapa masalah yang alami remaja dalam memenuhi tugas-tugas tersebut, diantaranya adalah masalah yang timbul akibat status yang tidak jelas pada remaja seperti masalah pencapaian kemandirian, kesalahpamahan atau penilaian berdasarkan stereotip yang keliru, serta adanya perubahan hormonal yang mengakibatkan remaja berada pada masa yang sulit. Pada fase ini akan ditandai dengan kecenderungan munculnya perilaku menyimpang. Salah satu bentuk penyimpangan perilaku yang sering terjadi di sekolah adalah perilaku Bullying.

Fenomena Bullying merupakan potret dari kehidupan manusia yang penuh ejekan, penghinaan, pengucilan, ketidakadilan dan kekerasan akibat dari budaya yang mengutamakan kekuasaan dan memanfaatkan kekuasaan bagi kesenangan pribadi yang menjadi gambaran keseharian yang berlangsung hampir disetiap kehidupan manusia yang berkelompok. Menurut Hidayati (2012), fenomena bullying ibarat fenomena gunung es yang nampak "kecil" dipermukaan, namun menyimpan berjuta permasalahan yang kasat mata oleh orangtua, bahkan orangtua seringkali meremehkan fenomena bullying sehingga mengesampingkan dampak buruk yang terjadi. Dalam kenyataannya, kasus bullying yang dilakukan tidak lepas dari pengaruh "pewarisan ideologi" dari para lulusan. Bullying sering di jumpai diberbagai sekolah dari TK hingga Perguruan Tinggi bahkan ada juga bullying ditempat kerja. Bullying merupakan salah satu bentuk tindakan agresif untuk mendominasi, menyakiti, menyerang atau mengasingkan orang lain yang lebih lemah dibandingkan dirinya atau kelompoknya.

Di Indonesia sendiri banyak kejadian yang menunjukkan bahwa dunia pendidikan Indonesia telah terjadi tindakan bullying terhadap siswanya. Fakta yang didapat dari penelitian yang di lakukan Yayasan Sejiwa (2008), menyatakan tidak ada satu pun sekolah yang bebas dari Bullying bahkan di beberapa sekolah swasta terkemuka sendiri praktek bullying berlanjut hingga di luar sekolah.

Fenomena bullying di sekolah menengah atas di Kota Kupang merupakan fenomena yang dianggap sebagai perilaku yang biasa atau hal tersebut merupakan tradisi oleh guru maupun siswa yang terbawa saat masa orientasi. Guru BK di sekolah tersebut mengatakan bahwa penanganan terhadap siswa yang melakukan bullying hanya diberikan kepada mereka yang 
melakukan bullying. Tetapi korban tidak dijamin untuk bebas dari perilaku bullying yang dialami. Selain itu hasil wawancara dengan beberapa murid di sekolah tersebut, mereka mengatakan bahwa perilaku bullying merupakan hal yang biasa dilakukan di sekolah, bullying dilakukan setiap ada kesempatan (Wawancara pribadi, Maret 2016).

Bullying didefinisikan sebagai penggunaan kekuatan atau status oleh seseorang untuk melukai, mengancam, atau mempermalukan orang lain. Bullying dapat bersifat fisik, verbal atau sosial. Tidak dikatakan bullying apabila dua siswa atau siswi berbeda atau bertengkar dengan kekuatan yang sama (Olweus and Solberg Works, 2003). Menurut Olweus dan Solberg (2003) tiga elemen utama dari definisi bullying adalah niat untuk menyakiti korban, sifatnya berulang dan ketidakseimbangan kekuasaan antara korban dan pelaku. Selain itu bullying juga didefinisikan dalam berbagai literatur sebagai perilaku berulang (termasuk perilaku verbal dan fisik) yang terjadi dari waktu ke waktu dalam hubungan yang ditandai dengan ketidakseimbangan kekuatan dan kekuasaan. Sebagian bullying dilihat sebagai agresi proaktif karena mengganggu dengan mencari target mereka, dengan sedikit provokasi dan dilakukan untuk waktu yang lama (Espelage dan Holt, 2007).

Bullying kerap kali membuat korbannya merasakan dan mengalami perasaan tertekan, tidak berdaya, bahkan sampai mengalami trauma. Hal tersebut masih saja dilakukan oleh pelaku dengan mengatasnamakan senioritas. Menurut Haryana (2008), pendiri Yayasan Semai Jiwa Amini (SEJIWA), lama-lama bullying dan tindakan semacam ini dianggap wajar. Hampir semua orang tidak menyadari dampak jangka panjang yang ditimbulkan pada korban dan pelaku.

Dampak lain yang muncul bagi korban maupun pelaku (Rigby, 2003), bagi korban tindakan bullying memberikan efek seperti psycological well-being yang rendah seperti perasaan tidak bahagia secara umum, self-esteem rendah dan perasaan marah dan sedih, penyesuaian sosial yang buruk seperti munculnya perasaan benci terhadap lingkungan sosial seseorang, mengekspresikan ketidaksenangan pada sekolah, merasa kesepian, merasa terisolasi dan sering bolos, selain itu korban juga akan mengalami psycological distress di mana subjek memiliki tingkat kecemasan yang tinggi, depresi dan yang paling buruk korban akan memiliki pikiranpikiran untuk bunuh diri. Korban akan mengalami psysical unwellness dimana subjek mengalami psikosomatis. Bulllying ternyata tidak hanya memberi dampak negatif pada korban, melainkan juga pada para pelaku. Bullying, dari berbagai penelitian, ternyata berhubungan dengan meningkatnya tingkat depresi, agresi, penurunan nilai akademik dan tindakan bunuh diri. Hasil penelitian Sejiwa (2008) yang dilakukan di 40 sekolah pada bulan April 2006 menunjukkan, salah satu penyebab bullying adalah kurangnya pendidikan disiplin dari guru dan orangtua. 
Aspek-aspek perilaku bullying menurut Colorosa dan Ericson (dalam Lizt, 2005), yaitu: (a) Bullying secara verbal. Bullying atau intimidasi secara verbal ditandai dengan memberi nama panggilan, mengejek, meremehkan, mengkritik secara tajam, memfitnah RAS, pelecehan seksual, pemerasan, mengganggu lewat telepon atau email. Mengintimidasi secara verbal termasuk intimidasi yang tergolong kasat mata namun sangat di berbahaya atau sangat berdampak buruk bagi korban karena dilakukan secara berulangkali. (b) Bullying secara fisik. Intimidasi dalam bentuk fisik adalah bentuk intimidasi yang paling mudah terlihat. Hal ini terwujud seperti menampar, memukul, mencolek, menendang, menggigit, mencakar, meludah atau bentuk melukai yang lainnya. Mengintimidasi secara fisik sangat membahayakan tubuh orang lain (korban). (c) Bullying secara emosional. Intimidasi secara emosional atau psikologis biasanya berbentuk mengabaikan, mengisolasi korban dari teman-teman, merusak hubungan orang lain juga beberapa intimidasi psikologis lainnya. Dalam intimidasi bentuk ini, pelaku biasanya meyakinkan orang lain untuk menolak korban sehingga secara otomatis korban akan terasingkan dari lingkungan sosial.

Quiros (dalam Anesty, 2009) mengemukakan sedikitnya terdapat tiga faktor yang dapat menyebabkan perilaku bullying, sebagai berikut: (a). Teman sebaya. Salah satu faktor dari perilaku bullying pada remaja disebabkan oleh adanya teman sebaya yang memberikan pengaruh negatif dengan cara menyebarkan ide (baik secara pasif maupun aktif) bahwa bullying bukanlah suatu masalah besar dan merupakan suatu hal yang wajar untuk dilakukan. Jadi bullying terjadi karena adanya tuntutan konformitas. (b) Pengaruh Media. Survey yang dilakukan harian kompas memperlihatkan bahwa 56,9\% anak meniru adegan-adegan film yang ditontonnya, umumnya mereka meniru geraknya (64\%) dan kata-katanya (43\%). (c) Hubungan kelekatan ibu dan anak. Anak akan meniru berbagai nilai dan perilaku anggota keluarga yang ia dilihat sehari-hari sehingga menjadi nilai dan perilaku yang ia anut (hasil dari imitasi). Sehubungan dengan perilaku imitasi anak, jika anak dibesarkan dalam keluarga yang mentoleransi kekerasan atau bullying maka ia mempelajari bahwa bullying adalah perilaku yang bisa diterima dalam membina satu hubungan atau dalam mencapai apa yang diinginkan, sehingga kemudian ia meniru (imitasi) perilaku bullying tersebut.

Gilham \& Thomson (1996) menyatakan perilaku anak merupakan hasil pembelajarannya terhadap apa yang terjadi di dalam rumah dengan orangtuanya sebagai "role model'. Hubungan antara orangtua dan anak merupakan hubungan pertama yang dimiliki seorang anak. Selanjutnya Gilham dan Thomson juga menyatakan peran anak dalam tindakan bullying (sebagai korban atau pelaku) salah satunya dapat dijelaskan melalui hubungan yang dimilikinya dengan orang tuanya. Hubungan yang terjalin antara orang tua dan anaknya disebut sebagai attachment. 
Kelekatan (attachment) untuk pertama kalinya dikemukakan oleh seorang psikolog dari Inggris pada tahun 1958 bernama Bowlby. Kemudian formulasi yang lebih lengkap dikemukakan oleh Ainsworth pada tahun 1969 (Mc Cartney dan Dearing, 2002). Kelekatan merupakan suatu ikatan emosional yang kuat yang dikembangkan anak melalui interaksinya dengan orang yang mempunyai arti khusus dalam kehidupannya, biasanya orang tua (Mc Cartney dan Dearing, 2002).

Bowlby (dalam Haditono dkk, 1994) menyatakan bahwa hubungan kelekatan akan bertahan cukup lama dalam rentang kehidupan manusia yang diawali dengan kelekatan anak pada ibu atau figur lain pengganti ibu. Pengertian ini sejalan dengan apa yang dikemukakan Ainsworth mengenai kelekatan. Ainsworth (dalam Hetherington dan Parke, 2001) mengatakan bahwa kelekatan adalah ikatan emosional yang dibentuk seorang individu dengan orang lain yang bersifat spesifik, mengikat mereka dalan suatu kedekatan yang bersifat kekal sepanjang waktu. Kelekatan merupakan suatu hubungan yang didukung oleh tingkah laku lekat (attachment behavior) yang dirancang untuk memelihara hubungan tersebut (Durkin, 1995). Tidak semua hubungan yang bersifat emosional atau afektif dapat disebut kelekatan. Adapun ciri afektif yang menunjukkan kelekatan adalah: hubungan bertahan cukup lama, ikatan tetap ada walaupun figur lekat tidak tampak dalam jangkauan mata, bahkan jika figur digantikan oleh orang lain dan kelekatan dengan figure lekat akan menimbulkan rasa aman (Ainsworth dalam Adiyanti, 1985).

Karakter yang multidimensional dari kelekatan secara implisit ada dalam teori kelakatan maupun penelitian mengenai kelekatan (Parkes and Stevenson-Hinde, 1982). Dua dimensi utama dari kelekatan disarankan diperoleh dari literatur; aspek perilaku dan aspek afektif/kognitif (cf. Hinde, 1982). Penelitian observasional pada bayi mengukur bentuk dimensi dapat disimpulkan dari pengalaman afektif. Sebagai peningkatan kapasitas kognitif, perilaku kelekatan secara teori diarahkan secara kognitif berdasarkan "working based" dari figur kelekatan. Kegunaan dari instrumen laporan diri untuk mengukur kelekatan remaja, lebih baik dari prosedur observasional, sehingga dapat ditekankan tidak hanya elemen perilaku dari pencarian kedekatan pada remaja dan pencarian dukungan, tetapi juga secara afektif yang berkaitan dengan harapanharapan kognitif merupakan bagian dari "model kerja internal" setiap individu yang memiliki figur kelekatan (Bretherton, 1985). 2 dimensi ini dapat diharapkan untuk berkorelasi. Penggunaan laporan diri merefleksikan pandangan bahwa kelekatan merepresentasikan aspek dari suatu hubungan dari sudut pandang satu individu dalam dia, dalam kasus ini, para remaja.

Menurut teori kelekatan Bowlby (1982) mengembangkan sebuah pengukuran laporandiri atas dimensi-dimensi perilaku dan afektif/kognitif kelekatan remaja pada orang tua dan rekan sebayanya. Mereka menemukan bahwa kelekatan remaja berusia 12-19 tahun pada orang tua 
dan rekan sebaya berhubungan dengan harga diri dan kepuasan hidup (koefisien korelasi adalah antara 0,30 dan 0,40) yang menunjukkan peran dari kelekatan dalam kesejahteraan psikologis, sebagaimana dipostulatkan oleh para pakar kelekatan. Sementara pengukuran Greenberg menyediakan pembenaran yang lebih besar pada sifat kelekatan pada remaja, reabilitas skalanya hanya bersifat moderat. Kemudian, karena dimensi afektif adalah uni faktorial, eksplorasi atas perbedaan individual dalam sifat kelekatan bersifat terbatas. Lewat pengujian dimensi kualitatif kelekatan, peranan dimensi afektif dalam kelekatan mungkin dapat diteliti.

Bowlby, Greenberg dan koleganya (1984) mengatakan bahwa "model kerja internal" dari sosok lekat mungkin dapat dikaji dengan mengukur (1) pengalaman afek atau kognitif yang positif dari kepercayaan dalam aksesibilitas dan responsivitas figur lekat. Dan (2) pengalaman afektif/kognitif atas rasa marah dan/atau ketidakberdayaan yang dihasilkan dari perilaku yang tidak responsif atau sosok lekat yang responsif secara tidak konsisten. Karena sebuah pertanyaan utama yang diarahkan dalam penelitian ini mengikuti kontroversi terbaru berkaitan dengan dampak yang berbeda atas pengaruh orang tua dan rekan sebaya, kami memilih untuk tidak mempertanyakan hubungan antara ibu dan ayah, atau tentang tipe hubungan yang berbeda dengan rekan sebaya. Malahan sebagai sejumlah figur (orang tua atau rekan sebaya) mungkin secara berbeda yang dapat memengaruhi remaja, kami mengarahkan remaja sebagai partisipan penelitian untuk menjawab pertanyaan mengenai responnya berkaitan dengan orang tua atau rekan sebaya yang paling berpengaruh terhadapnya.

Bailey (1988) melakukan penelitian tentang agresi pada anak yang diterbitkan dalam bukunya yang berjudul agresi dan kekerasan. Bailey menjelaskan bahwa anak yang mempunyai kecenderungan agresi mungkin merupakan manifestasi dari apa yang dilihatnya dari keluarga dalam hal ini orangtua. Anak melihat orangtua bertengkar, suka menghukum, tidak memiliki kesamaan pada saat membimbing, dan saling merendahkan martabat satu sama lainnya. Agresi ini terjadi sebagai jawaban atas rasa kecewa, nyeri dan ancaman tertentu. Ketika pelaku menemukan target yang tepat, maka endapan tersebut akan meledak. Apabila target tersebut adalah orang yang posisinya lebih lemah, maka perilaku ini biasa disebut sebagai Bullying. Beberapa penelitian telah dilakukan untuk melihat hubungan orangtua dan anak yang implikasinya berdampak pada tindakan anak melakukan bullying di sekolah. Manning, dkk (dalam Beaty \& Alexeyew, 2008) menjelaskan bahwa keluarga memiliki pengaruh yang sangat besar terhadap anak yang melakukan bullying. Rutter (dalam Beaty \& Alexeyew, 2008) lebih dalam lagi menyatakan bahwa hubungan yang baik antara anak dan orangtua sangat berpengaruh dalam pencegahan anak melakukan bullying. Hal ini senada dengan penelitian yang dilakukan oleh Namsel, et al. (dalam Beaty \& Alexeyew, 2008) yang menjabarkan kondisi para bullies yang biasa 
berasal dari keluarga yang memiliki kesulitan dalam hubungan orangtua dan anak, kesulitan finansial, kesulitan dalam pernikahan dan masalah sosial dalam lingkungan sekitar

Berdasarkan hasil penelitian-penelitian yang telah dilakukan, peneliti tertarik untuk mengangkat masalah pola attachment yang dikembangkan oleh orang tua sangat berpengaruh pada perilaku anak. Bahkan dalam penelitian yang dilakukan oleh Atkinson dan Tardif tahun 2001 (dalam Shaffer, 2002) didapatkan hasil bahwa remaja yang memiliki pola attachment insecure dengan orangtua di masa kanak-kanak menunjukan ketidakmampuan menjalin hubungan dengan teman sebaya, memiliki sedikit teman dekat, dan menunjukan perilaku menyimpang.

Selain itu pola atachment antara anak dan orangtuanya dapat diteliti tidak hanya pada saat anak menginjak usia balita tetapi pada tiap tahap usia perkembangan anak. Kualitas attachment yang dimiliki antara anak dan orangtuanya mempengaruhi perilaku anak bahkan sampai usianya menginjak masa dewasa. Hal ini disebabkan kualitas attachment cenderung stabil dari tahun ke tahun (Shaffer, 2002). Berdasarkan penelitiannya, Hamilton dan Waters (dalam Shaffer, 2002) menyatakan bahwa mayoritas orang dewasa dan remaja menampilkan pola attachment yang sama terhadap orangtuanya sebagaimana yang ditampilkan pada saat mereka masih balita. Apabila remaja pada masa lalunya mendapat pola insecure attachment maka hal ini bisa berpengaruh pada interaksinya dengan teman sebaya. Hal ini membuat peneliti tertarik untuk mengetahui apakah ada hubungan yang negatif dan signifikan antara kelekatan ibu dan anak dengan perilaku anak remaja di SMA negeri 3 di kota kupang.

\section{HIPOTESIS}

Ada hubungan yang negatif dan signifikan antara kelekatan ibu dan anak dengan perilaku anak remaja di SMA negeri 3 di Kota Kupang.

\section{METODE PENELITIAN}

Metode penelitian yang digunakan adalah metode kuantitatif. Menurut Juliansyah Noor (2011), penelitian kuantitatif merupakan metode untuk menguji teori-teori tertentu dengan cara meneliti hubungan antar variabel. Variabel tersebut diukur dengan menggunakan instrumen penelitian sehingga data yang terdiri angka-angka dianalisis berdasarkan prosedur statistika.

\section{Variabel Penelitian}

Adapun variabel-variabel dalam penelitian adalah :

1. Variabel terikat $(\mathrm{Y})$ : Bullying 
2. Variabel bebas $(\mathrm{X})$ : $\quad$ Kelekatan Ibu dan Anak

\section{Populasi dan Sampel Penelitian}

Azwar (2010) mendefinisikan populasi sebagai kelompok subjek yang hendak dikenai generalisasi hasil penelitian. Berdasarkan pengertian tersebut, maka populasi dalam penelitian ini adalah siswa SMA Negeri 3 Kupang kelas XI sebanyak 198 siswa.

Sampel merupakan sebagian dari populasi (Azwar, 2010). Dalam penelitian ini, sampel yang digunakan adalah seluruh siswa SMA Negeri 3 Kupang yang didapatkan melalui teknik sampling jenuh. Teknik sampling jenuh adalah teknik pengambilan sampel dengan mengambil semua anggota populasi menjadi sampel penelitian (Sugiyono, 2009).

\section{Teknik Pengumpulan Data}

Metode pengumpulan data yang digunakan dalam penelitian ini adalah metode angket atau skala pengukuran psikologi. Angket atau skala merupakan kumpulan dari pertanyaanpertanyaan atau pernyataan-pernyataan yang diajukan secara tertulis kepada responden untuk menjawabnya (Sugiyono, 2012).

Data penelitian diperoleh dari dua skala yang masing-masing mengukur variabel perilaku bullying dan kelekatan ibu dan anak.

\section{Skala Perilaku Bullying}

Skala yang di gunakan untuk melihat perilaku bullying adalah skala bullying. skala ini menggunakan aspek menurut Colorosa dan Ericson (dalam Lizt, 2005), yang terdiri dari 3 aspek yaitu : Bullying secara verbal, bullying secara fisik dan bullying secara emosional. Skala bullying terdiri dari 36 item dan menyediakan 4 pilihan jawaban, antara lain : SS (Sangat Sering), S (Sering), KK (Kadang-kadang), TP (Tidak Pernah).

Berdasarkan pada perhitungan uji seleksi item dan reliabilitas skala komunikasi interpersonal sebanyak dua kali putaran, yang terdiri dari 36 item, diperoleh item yang gugur sebanyak 7 item sehingga menyisahkan 29 item yang valid dengan koefisien korelasi item totalnya bergerak antara 0,258-0,661.

Sedangkan teknik pengukuran untuk menguji reliabilitas adalah menggunakan teknik koefisien Alpha Cronbach, sehingga dihasilkan koefisien Alpha pada skala Perilaku Buulying sebesar 0,895. Hal ini berarti skala Perilaku Bullying reliabel (Azwar, 2010).

\section{Skala Kelekatan Ibu dan Anak}

Skala Inventory of Parent and Peer Attachment (IPPA) adalah adalah skala yang digunakan untuk mengukur kelekatan antara ibu dan anak (Armsden, McCauley, Greenberg, 
Burke, Mitchell, 1991). Skala Inventory of Parent and Peer Attachment (IPPA) menggunakan skala Likert yang terdiri dari 25 item dan menyediakan 5 pilihan jawaban, antara lain : SS (Sangat Setuju), S (Setuju), KK (Kadang-kadang), TS (Tidak Setuju), dan STS (Sangat Tidak Setuju).

Berdasarkan pada perhitungan uji seleksi aitem dan reliabilitas skala kelekatan antara ibu dan anak sebanyak dua kali putaran, yang terdiri dari 25 aitem, diperoleh aitem yang gugur sebanyak 5 aitem sehingga menyisahkan 20 aitem yang valid dengan koefisien korelasi item totalnya bergerak antara 0,281-0,625.

Sedangkan teknik pengukuran untuk menguji reliabilitas adalah menggunakan teknik koefisien Alpha Cronbach, sehingga dihasilkan koefisien Alpha pada skala kelekatan ibu dan anak sebesar 0,859. Hal ini berarti skala kelekatan ibu dan anak reliabel (Azwar, 2010).

\section{Teknik Analisis Data}

Penghitungan penelitian ini menggunakan bantuan program statistik komputer IBM SPSS versi 16.00. Untuk menguji validitas item pada penelitian ini menggunakan Spearman (Azwar, 2009). Sedangkan untuk menguji reliabilitas pada penelitian ini menggunakan Cronbach Alpha. Pengujian normalitas pada penelitian ini menggunakan Kolmogorov-Smirnov, untuk uji linearitas digunakan ANOVA table of linearity, sedangkan pengujian hipotesisnya dan korelasi antara dimensi konflik peran ganda dengan dukungan sosial suami menggunakan Spearman rho.

\section{HASIL PENELITIAN}

\section{Uji Deskriptif Statistika}

Tabel 1. Dekriptif Statistika

Descriptive Statistics

\begin{tabular}{|l|l|l|l|l|l|}
\hline & N & Minimum & Maximum & Mean & $\begin{array}{l}\text { Std. } \\
\text { Deviation }\end{array}$ \\
\hline Bullying & 198 & 29 & 95 & 53.37 & 14.514 \\
Kelekatan & 198 & 41 & 95 & 77.73 & 10.276 \\
$\begin{array}{l}\text { Valid N } \\
\text { (listwise) }\end{array}$ & 198 & & & & \\
\hline
\end{tabular}

Berdasarkan tabel 1, tampak skor empirik yang diperoleh pada skala perilaku Bullying skor paling rendah adalah 29 dan skor paling tinggi adalah 95, rata-ratanya adalah 53,37 dengan standar deviasi 14,514. Untuk skala kelekatan ibu dan anak skor paling rendah adalah 41 dan skor paling tinggi adalah 95, rata-ratanya adalah 77,73 dengan standar deviasi 10,276.

Dengan demikian, maka norma kategorisasi hasil pengukuran skala bullying dengan kelekatan ibu dan anak dapat dilihat pada tabel berikut : 
Tabel 2. Kategorisasi Pengukuran Skala Perilaku Bullying dan Kelekatan Ibu dan anak

\begin{tabular}{|c|c|c|c|c|c|}
\hline Variabel & Interval & Kategori & Mean & $\mathbf{F}$ & Persentase \\
\hline \multirow[t]{7}{*}{$\begin{array}{l}\text { Perilaku } \\
\text { Bullying }\end{array}$} & $81,8 \leq x \leq 95$ & $\begin{array}{l}\text { Sangat } \\
\text { Tinggi }\end{array}$ & & 4 & $2,02 \%$ \\
\hline & $68,6 \leq x<81,8$ & Tinggi & & 29 & $14,65 \%$ \\
\hline & $55,4 \leq x<68,6$ & Sedang & & 53 & $26,77 \%$ \\
\hline & $42,2 \leq x<55,4$ & Rendah & 53,37 & 66 & $33,33 \%$ \\
\hline & $29 \leq x<42,2$ & $\begin{array}{l}\text { Sangat } \\
\text { Rendah }\end{array}$ & & 46 & $23,23 \%$ \\
\hline & \multicolumn{2}{|l|}{ Jumlah } & & $\begin{array}{l}19 \\
8\end{array}$ & $100 \%$ \\
\hline & \multicolumn{5}{|c|}{ SD = 14,514 Min = $29 \operatorname{Max}=95$} \\
\hline \multirow{7}{*}{$\begin{array}{l}\text { Kelekatan } \\
\text { Ibu dan Anak }\end{array}$} & $84,2 \leq x \leq 95$ & Sangat Tinggi & & 58 & $29,30 \%$ \\
\hline & $73,4 \leq x<84,2$ & Tinggi & 77,73 & 86 & $43,43 \%$ \\
\hline & $62,6 \leq x<73,4$ & Sedang & & 38 & $19,19 \%$ \\
\hline & $51,8 \leq x<62,6$ & Rendah & & 12 & $6,06 \%$ \\
\hline & $41 \leq x<51,8$ & $\begin{array}{l}\text { Sangat } \\
\text { Rendah }\end{array}$ & & 4 & $2,02 \%$ \\
\hline & \multicolumn{2}{|l|}{ Jumlah } & & $\begin{array}{l}19 \\
8\end{array}$ & $100 \%$ \\
\hline & \multicolumn{5}{|c|}{ SD = 10,276 Min = $29 \operatorname{Max}=95$} \\
\hline
\end{tabular}

Berdasarkan tabel 2 di atas dapat dilihat bahwa ada 4 subjek yang memiliki skor pada skala perilaku bullying yang berada pada kategori sangat tinggi dengan presentase 2,02\%, 29 subjek memiliki skor perilaku bullying yang berada pada kategori tinggi dengan persentase 14,65\%, 53 subjek memiliki skor perilaku bullying yang berada pada kategori sedang dengan persentase $26,77 \%$, 66 subjek memiliki skor perilaku bullying yang rendah dengan persentase 33,33\% dan 46 subjek memiliki skor perilaku bullying yang sangat rendah dengan presentase $23,23 \%$. Berdasarkan rata-rata sebesar 53,57 dapat dikatakan bahwa rata-rata perilaku bullying subjek berada pada kategori rendah.

Sedangkan untuk skala kelekatan ibu dan anak dapat dilihat ada 58 subjek yang berada pada kategori sangat tinggi dengan presentase 29,30\%, 86 subjek memiliki kategori tinggi dengan presentase 43,43\%, 38 subjek memiliki skor kelekatan ibu dan anak yang berada pada kategori sedang dengan persentase 6,06\%, 12 subjek memiliki kelekatan ibu dan anak yang rendah dengan persentase $6,06 \%$ dan 4 subjek memiliki skor kelekatan ibu dan anak yang dangat rendah dengan presentase 2,02\%. Berdasarkan rata-rata sebesar 77,73\% dapat dikatakan bahwa rata-rata kelekatan ibu dan anak subjek berada pada kategori tinggi. 


\section{Uji Asumsi}

Uji asumsi yang dilakukan terdiri dari uji normalitas, uji linearitas, uji multikolinearitas dan uji heteroskedastisitas. Uji normalitas dapat dilihat pada tabel berikut ini:

\section{Tabel 3. Uji Normalitas}

One-Sample Kolmogorov-Smirnov Test

\begin{tabular}{|ll|l|l|}
\hline & & Bullying & Kelekatan \\
\hline $\mathrm{N}$ & & 198 & 198 \\
Normal Parameters $^{\mathrm{a}}$ & Mean & 53.37 & 77.73 \\
& Std. Deviation & 14.514 & 10.276 \\
Most Extreme & Absolute & .081 & .110 \\
Differences & Positive & .079 & .062 \\
& Negative & -.081 & -.110 \\
& & 1.134 & 1.546 \\
Kolmogorov-Smirnov Z & & .153 & .017 \\
\hline Asymp. Sig. (2-tailed) & &
\end{tabular}

Pada skala perilaku bullying diperoleh hasil skor sebesar 1,134 dengan probabilitas ( $p$ ) atau signifikansi sebesar 0,153 ( $p>0,05$ ), hasil ini menunjukan data yang tidak berdistibusi normal. Sedangkan pada skor kelekatan Ibu dan anak memiliki nilai K-S-Z sebesar 1,546 dengan probabilitas (p) atau signifikansi sebesar 0,017. Dengan demikian variabel memiliki distribusi yang tidak normal.

Sementara dari hasil uji linearitas dapat dilihat pada tabel berikut:

Tabel 4. Uji lienearitas

ANOVA Table

\begin{tabular}{|c|c|c|c|c|c|c|c|}
\hline & & & $\begin{array}{l}\text { Sum of } \\
\text { Squares }\end{array}$ & Df & $\begin{array}{l}\text { Mean } \\
\text { Square }\end{array}$ & $\mathrm{F}$ & Sig. \\
\hline \multirow{5}{*}{$\begin{array}{l}\text { Bullying * } \\
\text { Kelekatan }\end{array}$} & \multirow{3}{*}{$\begin{array}{l}\text { Between } \\
\text { Groups }\end{array}$} & (Combined) & 7752.999 & 43 & 180.302 & .823 & .769 \\
\hline & & Linearity & 521.566 & 1 & 521.566 & 2.380 & .125 \\
\hline & & Deviation from Linearity & 7231.433 & 42 & $\mid 172.177$ & .786 & .818 \\
\hline & \multicolumn{2}{|c|}{ Within Groups } & 33747.344 & 154 & 219.139 & & \\
\hline & \multicolumn{2}{|l|}{ Total } & 41500.343 & 197 & & & \\
\hline
\end{tabular}

Hasil uji linearitas menunjukan adanya hubungan yang linear antara perilaku bullying dan kelekatan ibu dan anak dengan Deviation from Linearity sebesar 0,818 ( $p>0,05)$. 


\section{Uji Korelasi}

Berdasarkan uji asumsi yang telah dilakukan, di ketahui bahwa salah satu data tidak berdistribusi normal. uji korelasi yang digunakan dalam penelitian ini adalah korelasi Spearman rho. Tabel 5 menunjukan hasil dari uji korelasi.

Tabel 5. Tabel Korelasi

\section{Correlations}

\begin{tabular}{|ll|l|l|}
\hline & & Bullying & Kelekatan \\
\hline Spearman's rho Bullying & $\begin{array}{l}\text { Correlation } \\
\text { Coefficient }\end{array}$ & 1.000 & -.115 \\
& Sig. (1-tailed) &. & .053 \\
$\mathrm{~N}$ & 198 & 198 \\
\hline Kelekatan & Correlation & -.115 & 1.000 \\
& $\begin{array}{l}\text { Coefficient } \\
\text { Sig. (1-tailed) }\end{array}$ & .053 &. \\
$\mathrm{~N}$ & 198 & 198 \\
\hline
\end{tabular}

Hasil uji korelasi menunjukan adanya korelasi negatif yang tidak signifikan antara perilaku bullying dengan kelekatan ibu dan anak, $r=-0.115$ dengan sig=0.053 ( $p>0,05)$. Hal ini berarti hipotesis penelitian yang menyatakan adanya hubungan negatif dan signifikan antara perilaku bullying dengan kelekatan ibu dan anak di SMA negeri 3 Kupang di tolak.

\section{PEMBAHASAN}

Hasil uji korelasi mengenai hubungan antara perilaku Bullying dan kelekatan ibu dan anak menunjukkan angka korelasi antara Bullying dan kelekatan adalah $-0,112(p<0,05)$ dan sig = 0,058 ( $p>0,05$ ). Hal ini berarti tidak ada hubungan yang signifikan antara perilaku bullying dan kelekatan antara ibu dan anak. Hasil penelitian ini tidak mendukung penelitian yang di lakukan oleh Rutter (dalam Beaty \& Alexeyew, 2008) lebih dalam lagi menyatakan bahwa hubungan yang baik antara anak dan orangtua sangat berpengaruh dalam pencegahan anak melakukan bullying. Hal ini senada dengan penelitian yang dilakukan oleh Namsel, et al. (dalam Beaty \& Alexeyew, 2008) yang menjabarkan kondisi para bullies yang biasa berasal dari keluarga yang memiliki kesulitan dalam hubungan orangtua dan anak, kesulitan finansial, kesulitan dalam pernikahan dan masalah sosial dalam lingkungan sekitar

Tidak adanya korelasi antara perilaku bullying dan kelekatan bisa dijelaskan dari beberapa hal sebagai berikut seperti di katakan pengalaman negatif (hinaan, memberikan julukan, hingga tindakan fisik) yang diterima siswa dari gurunya dapat memicu terjadinya bullying yang nantinya 
dilakukan oleh siswa tersebut. Bullying berkembang dengan pesat dalam lingkungan sekolah yang sering memberikan masukan negatif pada siswanya berupa pemberian hukuman yang dilakukan oleh guru yang tidak membangun sehingga tidak mengembangkan rasa menghargai dan menghormati antar sesama anggota sekolah (Annisa, 2012:20). Selain itu, pihak sekolah termasuk guru yang cenderung membiarkan aksi bullying tanpa memberikan bimbingan serta pengarahan pada pelaku membuat bullying tumbuh subur. Menurut Ponny (2008:8), sekolah yang biasanya terjadi kasus bullying pada umumnya kurang pengawasan dan bimbingan etika dari para guru dan petugas sekolah. hal ini senada seperti yang di akui oleh sekolah bahwa kurangnya edukasi dan pembinaan khusus dari pihak sekolah tentang perilaku bullying itu sendiri. Pelaku bullying seringkali tidak mendapatkan hukuman yang layak, selain itu juga pihak sekolah kurang mengawasi secara intensif terhadap anak-anak yang melakukan bullying sehingga perilaku ini seringkali terulang tanpa adanya penanganan khusus dari pihak sekolah.

Faktor lain yang diungkapkan adalah pengaruh teman sepermainan yang sering melakukan tindak bullying juga mempengaruhi perilaku anak. Temannya sering memukul, menendang hingga berkata kasar apabila ia (pelaku bullying) tidak melakukan sesuai kehendak temannya tersebut. Menurut Heri Surya (2005: 11), dalam kelompok bermain jika anak mempunyai teman-teman yang memiliki perilaku buruk seperti suka melawan, suka berkelahi dan sebagainya maka anak pun memiliki kecenderungan untuk meniru perilaku temannya tersebut. Alasan lain anak melakukan hal yang sama dengan temannya karena anak ingin diterima oleh temannya. Penerimaan dan pengakuan dari temannya akan mendorong anak untuk melakukan hal yang diminta oleh temannya tersebut. Hasil penelitian Levianti (2008) menyatakan bahwa anak akan melakukan konformitas sebagai upaya agar diterima oleh orang lain dimana ia akan menjadi apapun sebagaimana keinginan orang lain, termasuk mengubah perilaku agar serupa dengan orang lain. Hal ini senada dengan hasil wawancarai di sekolah tersebut, dimana setiap anak selalu mengikuti kemauan teman-temannya sehingga dapat di terima oleh kelompok mayoritas, jika anak tersebut tidak melakukan hal yang sama maka ia akan di tolak di dalam komunitas yang ada.

Dari uraian diatas, terlihat bahwa faktor kelekatan tidak ada hubungan dengan perilaku bullying yang di lakukan oleh anak tersebut hal ini di sebabkan karena ketika berada di sekolah anak tersebut akan melakukan tindakan bullying karena terpengaruh dari teman sebaya dan juga dari pihak sekolah sendiri tidak memberikan punisment yang membuat anak tersebut jera sehingga tidak melakukan bullying lagi. 


\section{KESIMPULAN DAN SARAN}

\section{Kesimpulan}

Berdasarkan hasil penelitian diperoleh kesimpulan sebagai berikut:

1. Dari hasil uji korelasi, menunjukkan bahwa ada hubungan negatif yang tidak signifikan antara perilaku bullying dengan kelakatan ibu dan anak remaja di SMA Negeri 3 kota Kupang.

2. Perilaku Bullying sebagian besar ada pada kategori rendah, sedangkan kelekatan ibu dan anak sebagian besar pada kategori tinggi.

\section{SARAN}

\section{Remaja}

Kelekatan merupakan faktor penting yang dapat membantu anak-anak untuk tidak melakukan perilaku bullying. Oleh karena itu remaja tersebut harus lebih membenahi diri dengan membangun kelekatan dengan ibu agar supaya perilaku bullying dapat dikurangi bahkan menghilangkan perilaku tersebut.

\section{Orangtua}

Peran orangtua untuk selalu memantau anak-anaknya bukan saja ketika berada di rumah tetapi juga ketika anak berada di sekolah orangtua harus bisa memantau setiap apa yang di lakukan oleh anak-anak di sekolah dengan cara membangun hubungan yang positif dengan pihak sekolah. Selain itu orangtua juga harus memantau faktor lain yang akan mempengaruhi perilaku anak-anaknya.

\section{Guru}

Guru diharapkan mampu untuk memberikan pendidikan yang lebih baik lagi kepada siswa agar siswa tidak melakukan perilaku seksual pranikah. Dengan pengawasan dari guru dan budaya atau lingkungan yang sehat, remaja akan melakukan hal-hal positif dan menghindari perilaku seksual pranikah.

\section{Penelitian Selanjutnya}

Perilaku bullying dengan kelekatan ibu dan anak diharapkan dapat di kaji lebih lanjut hal ini karena perilaku bullying menjadi masalah penting tetapi peneliti selanjutnya harus lebih luas dengan menambah variabel lain yang belum terungkap dalam penelitian ini. Selain itu, diharapkan pada penelitian selanjutnya dapat lebih memperhatikan efektifitas dan daya diskriminasi item dalam alat ukur yang dipakai supaya dapat mengungkap lebih dalam mengenai variabel yang akan diteliti karena akan mempengaruhi hasil penelitian. 


\section{DAFTAR PUSTAKA}

Annisa. (2012). Hubungan Antara Pola Asuh Ibu Dengan Perilaku Bullying Remaja. Fakultas IImu Keperawatan. Skripsi. Universitas Indonesia.

Adiyanti. M.G., (1985). Perkembangan Kelekatan Anak. Tesis. Yogyakarta: Program Studi Psikologi Pascasarjana UGM.

Anesty, E. (2009). Konseling kelompok behavioral untuk mereduksi perilaku bullying siswa sekolah menengah atas: penelitian eksperimen kuasi terhadap siswa kelas XI SMA Negri 10 Bandung. Fakultas Psikologi Pendidikan dan bimbingan UPI, Bandung.

Armsden, G.C., McCauley, E., Greenberg, M. T., Burke, P., \& Mitchell, J. (1991). Parent and peer attachment in early adolescence depression. Journal of Abnormal Child Psychology.

Azwar, S, 2009, Sikap Manusia, Teori dan Pengukurannya, Jakarta : Pustaka Pelajar

Azwar, S. (2012). Metode Penelitian. Yogyakarta: Pustaka Pelajar.

Bailey, R. H. \& pustaka time life (Eds.). (1988). Perilaku manusia kekerasan dan agresi. (Suwargono Wirono. Terj.) Jakarta: PT. Tira Pustaka.

Beaty, L. A. \& Alexeyev, E. B. (2008). The problem of School bullies: What the research tells us. Adolescence, 43, 169-180.

Bretherton. I. (1985). Attachment Theory: Retrospect and Prospect. In Bretherton, I., and Waters, E. (eds). Growing Points in attachment theory and research. Monograph of the society for research in child development, Vol. 50. (1-2. Serial No. 209). University of Chicago Press.

Bowlby, J. (1982) Attachment and Loss: Vol. 1, Attachment (2nd ed). New York: Basic

Durkin, K (1995) Developmental Social Psychology, Massachussets : Blackwell Publisher Inc.

Espelage, D. \& Holt, M. (2007). Perceived social support among bullies, victims, and bully-victims. J. Youth adolescence. Springer science business media. University of illinois as Urbanachampaign.

Gilham, B. \& Thomson, J. A. (1996). Chilid safety: problem and prevention from preschool to adolescene. London: Routledge \& Kegan.

Greenberg. M., Siegal, J., and Leitch, C. (1984). The nature and importance of attachment relationshipsto parents and parents and peers during adolescence. J. Youth adoles.

Haditono. (1994). Psikologi Perkembangan. Cetakan ke IX. Yogyakarta : Gadjah Mada University Press.

Heri Surya. (2005). Kiat Mengatasi Penyimpangan Perilaku Anak 2. Jakarta: PT. Elex Media Komputindo. 
Hetherington, E.M \& Parke R.D., (Ed). (2001). Child Psychology : A Contemporary View Point. 5th Edition. Mc Graw-Hill College.

Hidayanti, N. (2012). Bullying pada anak: Analisis dan Alternatif solusi. Jurnal, 14(01), 43-45.

Hinde, R. A. (1982). Attacment: Some Conceptual And Biological Issues. In parkes, C. M., Stevenson-Hinde, J. (eds), The place of attachment in human behavior. Basic Books, New York.

Hurlock, E. B. (1999). Psikologi perkembangan: Suatu pendekatan sepanjang Rentang kehidupan. Jakarta: Erlangga.

Levianti. (2008). Konformitas dan Bullying Pada Siswa. Jurnal Psikologi. Vol 6. No.1. 2008. 4.

Litz, E. W. (2005). An Analiysis of bullying behaviors at E. B. Stanley Middle School in abingdon, Virginia. (Doctoral Dissertation). Retrieved from: $\mathrm{Http}: / / \mathrm{dc}$.etsu.edu/cgi/viewcontent.cgi?article=2259\&context=etd

Mc Cartney, K. \& Dearing, E., (Ed). (2002). Child Development. Mc Millan Refference USA.

Noor. Juliansyah. (2011). Metodologi Penelitian, Prenada Media Group, Jakarta

Parkes, C. M., and Stevenson-Hinde, J. (Eds.) (1982). The Place of attacment in Human behavior.Basic books, New york.

Ponny Retno Astuti. (2008). Meredam Bullying: 3 Cara Efektif Menanggulangi Kekerasan Pada Anak. Jakarta: PT. Grasindo.

Rigby, Ken. (2003) . Bullying Among Young Children: A Guide for Teachers and Carers. Australia: Australian Government Attorney-General"s Department.

Sejiwa. (2008). Bullying: mengatasi kekerasan di sekolah dan lingkungan sekitar anak. Jakarta: Grasindo.

Shaffer, D.R. (2002). Childhood and Adolescence: Developmental Psychology. (6th ed.). USA: Wadsworth Group.

Solberg, M. \& Olweus, D. (2003). Prevalence estimation of school bullying with the olweus Bully/victim questionnare. Vol.29, 239-268.

Sugiyono. (2009). Metode Penelitian Bisnis (Pendekatan Kuantitatif, Kualitatif, dan R\&D).

Bandung: Alfabeta.

Sugiyono. 2012.Metode Penelitian Bisnis. Bandung : Alfabeta. 